\section{Perceptions and practices of Angolan health care professionals concerning intimate partner violence against women}

\author{
Percepções e práticas de profissionais de saúde \\ de Angola sobre a violência contra a mulher na \\ relação conjugal
}

\section{Percepciones y prácticas de los profesionales de salud de Angola sobre la violencia contra la mujer en la relación marital}

\begin{abstract}
${ }^{1}$ Escola Nacional de Saúde Pública Sergio Arouca, Fundação Oswaldo Cruz, Rio de Janeiro, Brasil.

Correspondence A. P. Ribeiro

Centro Latino-Americano de Estudos de Violência e Saúde Jorge Careli, Escola Nacional de Saúde Pública Sergio Arouca, Fundação Oswaldo Cruz.

Av. Brasil 4036, sala 700, Rio de Janeiro, RJ 21040-361, Brasil. adalpeixoto@yahoo.com.br
\end{abstract}

\begin{abstract}
This was a qualitative exploratory study with the objective of identifying perceptions and practices among health professionals in Angola concerning intimate partner violence against women. Semi-structured interviews were held with a senior health administrator, head nurses, medical directors, psychologists, and nurse technicians in three national hospitals in the capital city of Luanda. The perceptions of Angolan health professionals towards violence against women are marked by the cultural construction of woman's social role in the family and the belief in male superiority and female weakness. Despite their familiarity with the types of violence and the consequences for physical and mental health, the health professionals' practices in providing care for women in situations of violence focus on the treatment of physical injuries, overlooking the subjectivity and complexity of these situations. Recent inclusion of the issue in public policies is reflected in health professionals' practices and raises challenges for the health sector in caring for women in situations of violence.
\end{abstract}

Violence Against Women; Domestic Violence; Health Personnel
Edna de Fátima Gonçalves Alves do Nascimento 1 Adalgisa Peixoto Ribeiro 1 Edinilsa Ramos de Souza ${ }^{1}$

\section{Resumo}

Trata-se de um estudo qualitativo exploratório com o objetivo de identificar as percepções e práticas de profissionais de saúde de Angola em relação à violência contra a mulher na relação conjugal. Entrevistas semiestruturadas foram realizadas com macrogestor da saúde, enfermeiros diretores de enfermagem, médicos diretores clínicos, psicólogos e técnicos de enfermagem em três hospitais nacionais de Luanda. As percepções dos profissionais de saúde angolanos sobre a violência contra a mulher são marcadas pela construção cultural do papel social da mulher na família, pela crença na superioridade masculina e fragilidade feminina. Apesar de conhecerem os tipos de violência e suas consequências para a saúde física e mental, suas práticas na atenção às mulheres em situação de violência priorizam o tratamento das lesões físicas, sem contemplar a subjetividade e a complexidade dessas situações. A recente inclusão do tema nas políticas públicas se reflete nas práticas dos profissionais e determina os desafios para o setor na atenção à saúde das mulheres em situação de violência.

Violência Contra a Mulher; Violência Doméstica; Pessoal de Saúde 


\section{Introduction}

Violence against women, the object of this study, refers to gender-based acts of violence that result in physical, sexual, and emotional harm or suffering for women, including threats, coercion, or constraints on freedom in public or private life 1 . Some authors discuss how such violence is taken for granted and justified by the patriarchal order, in which men have the right to command and control women, resorting to violence for this purpose 2 .

The various manifestations of violence against women can cause physical and mental health problems and increased use of health services. Population studies show that $10 \%$ to $69 \%$ of women 15 to 49 years of age have been victims of physical violence perpetrated by intimate partners at least once in their lives ${ }^{3}$. A multi-country study on domestic violence found that $6 \%$ to $59 \%$ of the women interviewed had suffered sexual violence perpetrated by their partners sometime in life 4 .

Gender studies on violence against women, also identified as gender-based violence, involves aggressions based on power relations and cultural differences attributed to the sexes. Gender-based violence can include violence by men against women, by women against men, and also between women and between men, but women have been the most frequent victims in relations with men $2,5,6$.

In the specificity of intimate partner relations, intimate partner violence $7,8,9$ occurs regardless of social class, race, ethnicity, age, or sexual orientation 10 and is expressed as physical, sexual, emotional, or psychological and social aggression 5 .

Medium and low-income countries, with Angola as an example of the latter, suffer from a lack of data on violence against women, which contributes to the issue's invisibility. Data on intimate partner violence from the Ministry of the Family and Women's Protection (MINFAMU), recorded in the first quarter of 2006 at the Family Counseling Center, showed that of the 2,260 cases of violence in Luanda, $92.6 \%$ of the victims were women and $90.5 \%$ of the aggressors were men. At this institution, economic violence (denial of paternity, failure to pay child support, abandonment of the family, eviction of the woman, and expropriation of the woman's assets) is the most common complaint $(70.9 \%)$, followed by physical violence (10.5\%) and psychological violence $(8.9 \%) 11$.

Health services in Angola rarely identify or deal with violence in conjugal relations, a situation that hinders preventive measures. Consider- ing that these services can be an important portal of entry to support and protect women exposed to intimate partner violence and that seek help, public policies recommend offering expanded healthcare to these women, which incorporates comprehension and change of attitudes, beliefs, and practices, with a scope that extrapolates simple diagnosis and care for physical injuries and emotional trauma.

Given these elements and the magnitude of violence against women, the aim of this study is to identify the perceptions and practices of health professionals in Angola concerning intimate partner violence against women.

\section{Methodology}

A qualitative exploratory study was conducted in three national hospitals in the capital city of Luanda: Josina Machel Hospital, Lucrécia Paim Maternity Hospital, and Neves Bendinha Hospital. Josina Machel is a general hospital with 480 beds, treating approximately 200 emergency cases per day. In 2009 it treated 55,440 emergency cases. The Lucrécia Paim Maternity Hospital has an emergency ward and outpatient and inpatient services. It has 400 beds and treats approximately 200 women per day. In 2009, the emergency ward treated nearly 43,000 women. The Neves Bendinha Hospital is a referral center for burn patients with 60 beds.

These healthcare facilities were selected because they are national references for treating emergency cases and victims of intimate partner violence, but none of them systematically records the latter cases. Emergency care is a powerful indicator of violence in Luanda, since it is where victims turn in cases of trauma or imminent death. For many victims of violence, it is the only time they will be face-to-face with a health professional (a representative of public authority) and one of the only moments in which the violence will be reported 12 .

Thirteen semi-structured interviews were conducted with: a senior health administrator, three head nurses, three clinical medical directors (identified in the text as administrators), three psychologists, and three nurse technicians (identified as technicians), of both sexes. All had relatively extensive experience in their areas. They were referred to the study by the Division of Hospital Administration and the Ministry of Health. The health services authorized the study, and the subjects signed a free and informed consent form to participate in the interviews.

The interview script included questions on the professionals' perceptions towards the inti- 
mate partner violence suffered by women, their approach to these cases, and the role of health services in dealing with violence. The interviews were taped, transcribed, and analyzed according to the thematic analysis technique adapted from Bardin by Minayo 13. The material was organized in a databank according to professional category and the themes discussed in the interviews. The material was later read exhaustively to identify core meanings that emerged in the previously defined themes. The analyses were presented according to these broader themes: perceptions towards intimate partner violence, care offered to women in situations of intimate partner violence, and challenges in providing care for these women.

The study was approved by the Ethics Research Committee of the Sergio Arouca National School of Public Health, Oswaldo Cruz Foundation (case review n. 167/10).

\section{Results and discussion}

"Women aren't prepared for married life": the perceptions of Angolan health professionals towards violence against women

The health professionals interviewed in this study defined violence against women as anything that jeopardizes their dignity, expressed by discrimination and denial of their rights: "In my opinion, intimate partner violence is violence at all levels. Whatever undermines the woman's dignity is violence" (administrator; female).

This kind of violence occurs between boyfriends and girlfriends, cohabiting couples, and in common law and official marriages. Some interviewees highlighted that women are the most frequent victims in relationships, but that they can also be the aggressors. Just as "many men kill women", "many women kill the men, hit them, assault them" (technician; male). According to this view, corroborating other studies 10,14, men can be victims of women, but the cruelty and severity suffered by men are normally less than the aggressions perpetrated by them.

The interviews showed that violence against women in intimate partner relations is manifested as different forms of physical aggression, like beatings, burns, firearm and knife wounds, sexual abuse, and psychological, economic, and even spiritual violence. According to these health professionals, sexual violence between spouses occurs as a form of coercion by the man against the woman, claiming that sexual intercourse is the wife's obligation, "even when the woman does not want [to have sex] or is unable for medical reasons, and even so the husband refuses to accept that she refuse to have sex" (technician; female). In such conditions, women sometimes resist but end up giving in, in order to protect themselves from physical aggression as a result of their refusal, to guarantee their financial support, and to avoid being accused of infidelity, apparently a common reaction in Angolan culture.

The reasons cited for violence include situations that spark jealousy. When a woman is seen talking to someone else, "There's no other way to solve the problem except throwing something at her" (technician; female). This excerpt from an interview with a female health professional shows that physical aggression is commonplace, even taken for granted, in resolving intimate partner conflicts.

According to the literature, other reasons frequently cited for aggression between intimate partners include the woman's refusal to have sexual relations, disobeying the husband, infidelity, failure to properly care for the children, challenging the husband on financial issues or extramarital relations 15 , stress, and use of alcohol and other drugs 16,17.

Alcoholism did not appear in the health professionals' discourse as a factor associated with intimate partner violence. However, Nascimento 18 found that in Kilamba Kiaxi, Angola, 18\% of interviewees pointed to alcohol use as a factor for physical violence against women.

Interviewees perceived that the aggressions negatively affect the woman's health and that of her family, and represent a public health problem. The most frequently cited physical consequences were: injuries, hypertension, burns, and death. Psychological trauma included depression, neglecting to seek medical services, phobias, suicide attempts and tendency, alcohol abuse, and post-traumatic stress disorder. They also cited psychological disorders during pregnancy, threats to the infant, miscarriage, premature childbirth, and even the woman's murder.

Other studies list as consequences of violence against women: muscle tension, gastrointestinal irritation, genital problems, sexually transmitted diseases, sexual dysfunction, unwanted pregnancy 19, emotional anxiety, and suicidal behavior 15 .

Some factors mentioned as associated with intimate partner violence appear to justify it and reinforce male domination. The historical male domination over women is considered a social problem that subjects women to sexual violence by the partner 20 . In African cultures, as in Mozambique for example, violence is a structural 
component of conjugal relations, reinforced by women themselves, who appear to grant the man this right 21 .

Administrators and technicians highlighted women's submission, their socioeconomic dependency on men, and unemployment as issues closely related to violence and that assign women the responsibility for the violence they suffer. This perception is marked by male chauvinist prejudices and values, even among women, still very strong in Angolan culture: “A woman who suffers violence is one who can't get by on her own, so she can't say no to her partner, and that's where violence comes in. (...) it's for lack of salt or sugar that a beating can happen when the man of the house is a chauvinist and raises his hand to strike her" (administrator; female). “...As long as she depends on him, she can't say a word. Whatever she says will lead to violence" (administrator; female).

Some say that breaking with this violent relationship can threaten her survival and that of the children, but overcoming this condition means achieving an equal footing with the man, allowing her to raise her self-esteem, freeing her from economic dependency and refusing to accept violence.

Contrary to this view, one of the interviewees mentioned that in some cases it is easier for the woman to find work and thus support the family. But this also generates intimate partner violence, since "...the man isn't used to the woman going out to work and coming home to find him doing nothing" (technician; male).

Following the civil war in Angola, the reintegration of former combatants into society was a complex process, since they returned to their communities without work and with the women heading, protecting, and supporting the family economically 21 . The fact that the man failed to meet expectations as family provider and that the woman earned better money can pose the risk of violence, leading the man to impose his authority by physical force, since this situation is a threat to his male identity and represents a break in the rules and beliefs that the man should not be supported by the woman 21,22,23.

The administrators emphasized gender inequalities, the biological, social, economic, and cultural factors that define men and women's roles in family and society. Male health professionals thus especially view women as weak, submissive, and helpless and thus more vulnerable to violence, which in turn helps perpetuate these inequalities: “...in a way this violence affects women because they're weaker, and the men sometimes use physical force and cause harm and injury to women" (administrator; female).
According to studies in more traditional societies, as in some African countries, violence against women is justified culturally, and women are assigned the role of keeping the home and family and the duty of obedience to (and respect for) the man's wishes 15 . The interviews with technicians clearly showed that a breach of roles culturally identified with the female gender, such as the woman "who doesn't make lunch, doesn't iron her husband's clothes" (technician; female) are cited as a woman's lack of preparedness for marriage and for fulfilling family duties, potentially triggering male violence. Thus, they believe that one has "to talk to women about their comportment in the home, prevent troubles by lecturing her, explaining women's duties within the family" (technician; female).

\section{"If there are physical injuries, we can treat them": care offered to women in situations of intimate partner violence in Angola}

The literature recommends that healthcare in suspected or confirmed cases of violence should include investigation, protection, and qualified listening, treatment of physical injuries and psychological trauma, and referral within and between sectors. Attention to this characteristic of care requires a trained multidisciplinary team with a broad, comprehensive view of women's health 23 .

In these three Angolan hospitals, women have a case history recorded in the emergency ward. If there is any suspicion of violence, identified mainly by physical injuries (uterine bleeding in pregnant women, burns, fractures), the nurse technicians question them about the circum stances in order to confirm the violence.

The analysis showed that a major share of the interviewees only provide traditional treatment, caring only for the victims' physical injuries and encouraging the victims to report to the police, but without referring them for psychological or social follow-up, partly because there are few psychologists or social workers in Angola, and few health services have them in their staff. They also feel that psychological violence is not a problem for hospital and claim that "the person doesn't come to the doctor to complain about psychological abuse" (administrator; male).

It became clear that the interviewees did not see possibilities for their own intervention and did not feel responsible for providing comprehensive care (beyond clinical procedures for treating physical injuries) or including a broader approach to the situations of violence suffered by women: “...we are a hospital, and our focus is more treatment-based, especially when there are 
physical injuries that we can treat" (administrator; female).

The literature has reiterated the frequent search for healthcare by victims and a response limited to the treatment of symptoms and lesions, neglecting the cause of the problem and perpetuating physical, psychological, and social harm 24 .

With this biologically-centered vision of care for victims of violence, the interviewees claimed that there was no difficulty in acting in such cases, as shown in these interviews:

"I don't think there's any major difficulty in dealing with these patients because our work here focuses more on the issue of medical treatment itself" (administrator; male).

"We don't experience major difficulties in treating people, because the hospital services are fully equipped and prepared to treat the patients that come to our emergency ward" (technician; female).

Importantly, there have been times in health services in Angola when patients had to purchase and bring the supplies used for their treatment in the hospitals.

According to the interviews, when the woman spontaneously reports the violence it facilitates treatment and referrals. However this does not guarantee follow-up on the case, which would require a referral and counter-referral system with well-defined flows and procedures, and such a system does not exist in Angola.

Psychologists and social workers act as facilitators in managing such cases, reinforcing the idea that victims should receive multidisciplinary care, but they only exist in one of these three healthcare facilities. Their reports suggested a careful and respectful encounter with these patients, establishing trust between the woman and the healthcare professional to talk about the violence, prioritizing the woman's self-esteem and decision-making capacity in dealing with intimate partner violence. Even without having received specific training on the subject, these professionals have endeavored to offer a more sensitive therapeutic approach, with orientation and counseling on the impact of violence on victims' health, as well as on their place in society. However, according to one study 24 , they do not identify such interventions as professional or scientific. On the contrary, they view them as outside the realm of their professional role and consider them personal advice or solidarity.

Although experts recommend treatment for the aggressor 25 , the nurse technicians reported that such contact is rare, but when they do succeed in establishing it, they counsel the aggressor by encouraging dialogue in the couple, aiming to interrupt the cycle of violence, as recommended in the country's Law against Domestic Violence (LVD) 26. The most common approach by technicians towards the perpetrator of the violence is to call the police, "who take the appropriate steps with the aggressor" (technician; female).

These healthcare facilities do not have any specific recording system for cases of violence against women, and the daily care is only recorded in a general log book. Pregnant women keep a prenatal card which includes the following question on violence: "Have you ever suffered any kind of violence?", with only two possible answers: physical violence and moral violence. Since women normally deny having suffered violence, this item on the card is never filled out. Women's denial is likely due to the bureaucratic way the question is addressed and the limited options for answering. Only one technician stated that the hospital where he works has a form to record cases of violence, which are referred to the police and the agency for women's defense.

\section{Major challenges for providing care to Angolan women in situations of intimate partner violence}

All the interviewees acknowledged that the services are not organized to offer specialized care for female rape victims. They emphasized difficulties in identifying and acting in these cases, highlighting women's silence. The fact that they fail to disclose the abuse calls for closer attention in evaluating injuries and confirming suspicions.

"The woman never admits that it was abuse. The physician suspects it for some reason, some injury in an unusual site, and in the course of the conversation she confirms that she was abused" (administrator; female).

According to one administrator, failure to speak about the violence can lead to repeated abuse. According to the technicians, this silence is due to cultural issues such as the tradition of woman's submission to her man or partner, discouragement from the family for complaints, counseling the couple to make amends, and fear over losing her home and social status or suffering further abuse. The technicians contend that women do not "want" to leave the situation of violence because they are not willing to radically change their living conditions. Ferrante et al. 27 found similar perceptions to those of the Angolan health professionals concerning women persisting in violent relationships.

In addition to the reasons identified by the interviewees, the following are common: the perception that violence is normal in intimate 
partner relations 28 , that there is still hope and love for the partner 19 , that the woman cannot find the words to express her problem, and difficult interpersonal relations between patients and health professionals, full of fears, prejudices, shame, and discredit 29.

For women to speak about their experience with violence is a complex issue. Violence appears to be equated with crimes committed by strangers and more dire situations. Domestic violence, even with serious consequences, is not normally viewed as such 29 .

The senior administrator identified the perception that this is a private problem between the couple in which health professionals should not get involved, since they would be invading privacy, and highlighted this perception as an obstacle to identifying intimate partner violence. This view indicates resistance and embarrassment among the health professionals in asking women about violence when they suspect it has occurred. Meanwhile, researchers indicate that health professionals should ask women clearly and objectively about their experience with violent situations, encouraging and allowing them to talk openly about the subject 23. Treating women in situations of violence involves values, decisions, and trust to provide care and knowledge about the actions in care and their consequences 30 .

A female administrator showed a discriminatory and judgmental attitude, ignoring women's reasons for omitting the violence and claiming that "they aren't capable of being sincere" in reporting the cause of their injuries, adding, "We want to treat them, but the women won't let us" (administrator; female).

The interviews show the need for the health professional to establish a relationship of trust, with respect and receptiveness. They contend that if a woman has been raped by her partner and persists in the relationship, it is because "she enjoys a beating", or that she "is not ashamed of herself" because she fails to leave the man, withdraws her complaint, and makes up with her aggressor. Such beliefs ignore the typical dynamics of intimate partner violence, in which a cycle of tension precedes the aggression, followed by a period of regret by the aggressor and a truce, followed by a new cycle of tension. They often blame the woman or overlook her complaint due to the services' disorganization or unpreparedness, leading to negative practices in care for the women ${ }^{31}$. One of the health professionals' difficulties in supporting victims of violence, especially sexual violence, is to overcome prejudices related to cultural and moral values in order to offer supportive and humanized care 32 .
Brazil has what is known as the Maria da Penha Law 33 , which criminalizes violence against a woman by her current or former intimate partner. The law protects the woman, preventing her from withdrawing the complaint. Angola has the LVD 26, the aim of which is to protect and assist victims and prevent such violence. It covers specific issues related to victims and aggressors, while aiming to promote gender equality.

In practice, the care provided by Angolan health professionals focuses more on medical specialties, which tends to overshadow their perception, involvement, and action and thus overlooking the biopsychosocial dynamics entailed in intimate partner violence. Like these professionals, some authors have highlighted the importance of a multidisciplinary team that would allow comprehensive care 10,12,15,34.

The reasons cited for this fragmented care are the limited number of health professionals, lack of a trained multidisciplinary team, and studies to orient management in case of violence. Other reasons that have been cited include the lack of healthcare referral services for treating victims, in the mistaken view that such care should be provided by a specialized service rather than by the entire healthcare system, as a crosscutting issue.

Angola's National Health Policy (PNS) acknowledge the quantitative and qualitative insufficiency of human resources and recommends hiring foreign healthcare workers to fill these gaps until consistent training of Angolan to work according to the new health technologies 35 .

Some interviewees acknowledged the importance of support from the inter-sector network, in agreement with the literature 36,37 . But the majority reported that the lack of linkage between health services and social structures for support and protection (MINFAMU, the Organization of Angolan Women, Ministry of Social Assistance and Reintegration) results in inadequate care that often perpetuates violent episodes. After clinical treatment, women victims of intimate partner violence are referred to support services where they receive follow-up on such issues as abandonment, denial of paternity, failure to pay child support, criminal prosecution of the aggressor for physical assault, or violation of legal rulings by one of the spouses. However, there is no counter-referral to the health services, which hinders the linkage with the network from women's protection in situations of violence, as provided by the PNS.

The interviewees were unanimous about the lack of professional training as the main difficulty for dealing with situations of violence. One administrator highlighted the need for awareness 
and skills to maintain control, self-command, and the capacity to orient victims of violence. This unpreparedness has been identified by many studies in the health field 16,20,38. Brazil has public health policies to orient such care, but there are still gaps in training for health professionals to provide this care 39 . In Angola, health policies include the issue of violence, although with a limited scope, and there is an urgent need for training, as recommended by the PNS 35 and the LVD 26. According to the administrators, awareness-raising and training for health professionals are essential to avoid women's repeated victimization. Their interviews reveal a form of institutional violence against woman, by failing to value their complaints and by offering treatment limited to clinical procedures, failing to take an expanded approach to the question.

Other issues that hinder and limit care are the lack of institutional support, absence of protocols with technical guidelines for care in such cases, women's lack of knowledge on psychological and social care (which are new specialties in the country), lack of implementation of the health policies orienting this care, the limited physical space of services (failing to guarantee patients' privacy), and the health professionals' work dynamics.

One administrator emphasized that the heavy work overload hinders in-depth investigation of violence, since many cases go unnoticed and the technicians "are not capable of that kind of expertise, suspecting and probing a little further" (administrator; male).

As strategies to overcome these challenges, the interviewees emphasized: organization of the health services at the various levels of care to implement measures for the prevention of violence against women, mobilization of human, material, and financial resources in health and other sectors, such as public security, justice, and work, in order to act jointly to care for women in situations of violence.

One administrator also called attention to the media's shared responsibility for educating people to prevent violence against women: "The mass media have the fundamental duty to communicate all this information and educate the population" (administrator; male).

\section{Final remarks}

The perceptions of Angolan health professionals concerning violence against women in intimate partner relations appeared heavily marked by the cultural construction of women's role in the family as mother and spouse. Their views are also heavily laden with prejudices grounded in purported male superiority, attributing the dominant role to men and identifying women as weak and helpless. These professionals were able to list types of violence and their consequences for physical and mental health, but their views expressed the hierarchical and asymmetric gender relations that foster violence, placing the responsibility on women for the aggression they suffer in this relationship.

Given this view of violence against women, the practices of these professionals in caring for victims take an essentially clinical focus, prioritizing the treatment of physical injuries while overlooking or failing to sufficiently contemplate the subjectivity and complexity of these situations. They do not always approach or are oriented to act with the individuals involved in these situations: the woman, the children, and much less the aggressor. Aggressors are rarely approached, and even then with a police view, taking a punitive approach to the case, showing that the health professionals mainly associate domestic violence with law enforcement in the belief that the police and courts should solve the issue. In short, in the view of the interviewees, intimate partner violence is only a matter for the social worker and psychologist, as well as the police and courts. In fact, the study showed that the psychologists were more sensitized than their colleagues from other health specialties to take a more appropriate approach to women in situations of intimate partner violence.

The PNS recently enacted in Angola acknowledges that women and children are the main victims of domestic violence. In its analysis of the health situation, the policy refers to physical and psychological violence as "an unhealthy lifestyle". However, it fails to provide specific guidelines to provide care for victims and prioritizes the prevention and treatment of infectious diseases, the predominant problem in health services in Angola. This timid and incipient inclusion of the issue in public policies is mirrored in the practices by health professionals and in the difficulties they experience, and determines the major challenges for the healthcare system in caring for women in situations of violence.

These challenges include: (1) administrator awareness-raising and staff training on the subject; (2) organization of healthcare services to provide care through interdisciplinary teams, with protocols, technical guidelines, referral and counter-referral flows; support for professionals involved in this care; recording and reporting of cases of violence to the health authorities; (3) establishment of an intra- and inter-sector network to support and care for victims; (4) 
approval and enforcement of measures to prevent violence against women as a responsibility of health professionals and services at all levels of care; (5) inclusion of aggressors and the guarantee of trained, sufficient staff to counsel and assist couples in resolving their conflicts without resorting to violence; and (6) promotion of changes in health professionals' concepts and practices in order to no longer take for granted the cultural values pertaining to women and violence, promoting healthcare in which users can receive skilled and humanized care.

As in Brazil and other countries with health policies recommending the prevention of violence and organization of services to care for victims, Angola also needs to take these steps. It

\section{Resumen}

Se trata de un estudio cualitativo exploratorio, con el objetivo de identificar las percepciones y prácticas de los profesionales de salud de Angola sobre la violencia contra la mujer en la relación marital. Se realizaron entrevistas semi-estructuradas con los administradores de salud, enfermeras jefa, médicos clínicos, psicólogos y personal de enfermería de tres hospitales de Luanda. Las percepciones de los profesionales de salud sobre la violencia contra las mujeres se caracterizan por la construcción cultural de la función social de la mujer en la familia, la creencia en la superioridad masculina y la fragilidad femenina. A pesar de conocer la violencia y sus consecuencias para la salud física y mental, sus prácticas de atención para mujeres en situación de violencia priorizan el tratamiento de las lesiones físicas, sin tener en cuenta la subjetividad y complejidad de estas situaciones. La reciente inclusión del tema en la política pública se refleja en las prácticas y determina los problemas del sector en el cuidado de la salud de las mujeres en situaciones de violencia.

Violencia Contra la Mujer; Violencia Doméstica;

Personal de Salud is necessary to give greater visibility to women's importance in society, their rights, their participation in the labor market, and even more urgently, to no longer take for granted the violence women suffer in their social relations, especially in intimate partner relations.

It is hoped that this study will help increase the visibility of the need to combat gender-based violence, so present in Angolan culture and society. Further developments of this process indicate the need for more in-depth knowledge, hearing the women and men involved in violent relations to learn how they perceive the work by health services and the possibilities for the health system to offer help in such cases.

\section{Contributors}

E. F. G. A. Nascimento participated in the data collection, processing, and analysis and writing of the article A. P. Ribeiro and E. R. Souza participated in the data processing and analysis, writing of the article, and approval of the final version.

\section{Acknowledgments}

The authors wish to thank the health professionals who kindly granted interviews. 


\section{References}

1. Hane B, Ellsberg M. Violência contra as mulheres: efeitos sobre a saúde reprodutiva. Outlook 2002; 20:1-8.

2. Araújo MF, Martins EJS, Santos AL. Violência de gênero e a violência contra a mulher. In: Araújo MF Mattioli OC, organizadores. Gênero e violência. São Paulo: Arte e Ciência; 2004. p. 17-36.

3. Organização Mundial da Saúde. Prevenção da violência sexual e da violência pelo parceiro íntimo contra a mulher: ação e produção de evidência. Washington DC: Organização Mundial da Saúde; 2012.

4. Garcia-Moreno C, Jansen HAFM, Ellsberg M, Heise L, Watts C. WHO multi-country study on women's health and domestic violence against women. Geneva: World Health Organization; 2005.

5. Gomes R, Minayo MCS, Silva CFR. Violência contra a mulher: uma questão transnacional e transcultural das relações de gênero. In: Secretaria de Vigilância em Saúde, Ministério da Saúde, organizador. Impacto da violência na saúde dos brasileiros. Brasília: Ministério da Saúde; 2005. p. 117-40.

6. Giffin K. Violência de gênero, sexualidade e saúde. Cad Saúde Pública 1994; 10 Suppl 1:146-55.

7. Pazo CG, Aguiar AC. Sentidos da violência conjugal: análise do banco de dados de um serviço telefônico anônimo. Physis (Rio J.) 2012; 22:253-73.

8. Schraiber LB, D'Oliveira AF. Violência contra mulheres entre usuárias de serviços públicos de saúde da grande São Paulo. Rev Saúde Pública 2007; 41:359-67.

9. Narvaz MG, Koller SH. Mulheres vítimas de violência doméstica: compreendendo subjetividades assujeitadas. Rev Saúde Pública 2006; 39:376-82.

10. Lamoglia CVA, Minayo MCS. Violência conjugal, um problema social e de saúde pública: estudo em uma delegacia do interior do estado do Rio de Janeiro. Ciênc Saúde Coletiva 2009; 14:595-604.

11. Ministério da Família e Promoção da Mulher. Dados estatísticos de violência, I trimestre 2006. Luanda: Ministério da Família e Promoção da Mulher; 2007.

12. Deslandes SF. O atendimento às vítimas de violência na emergência: "prevenção numa hora dessas?” Ciênc Saúde Coletiva 1999; 4:81-94.

13. Minayo MCS. O desafio do conhecimento. Pesquisa qualitativa em saúde. 9a Ed. São Paulo: Editora Hucitec; 2006

14. Reichenheim ME, Moraes CL, Szklo A, Hasselmann MH, Souza ER, Lozana JE, et al. The magnitude of intimate partner violence in Brazil: portraits from 15 capital cities and the Federal District. Cad Saúde Pública 2006; 22:425-37.

15. Krug EG, Dahlberg LL, Mercy JA, Zwi AB, Lozano R. Relatório mundial sobre violência e saúde. Genebra: Organização Mundial da Saúde; 2002.

16. Moreira SNT, Melo COM, Azevedo GD. Violência física contra a mulher na perspectiva de profissionais de saúde. Rev Saúde Pública 2008; 42:1053-9.

17. Minayo MCS, Deslandes SF. A complexidade das relações entre drogas, álcool e violência. Cad Saúde Pública 1998; 14:35-42.
18. Nascimento EFGA. Fatores determinantes da violência contra a mulher no município do Kilamba Kiaxi. Luanda: Universidade Agostinho Neto; 2005.

19. Almeida MV. Violência conjugal e álcool: (in)existência de uma relação causal? [Dissertação de Mestrado]. Coimbra: Universidade de Coimbra; 2009.

20. Oliveira CC, Fonseca RMGS. Práticas dos profissionais das equipes de saúde da família voltadas para as mulheres em situação de violência sexual. Rev Esc Enferm USP 2007; 41:605-12.

21. Moura T, Roque S, Araújo S, Rafael M, Santos R. Invisibilidades da guerra e da paz: violências contra as mulheres na Guiné-Bissau, em Moçambique e em Angola. Revista Crítica de Ciências Sociais 2009; 86:95-122.

22. Matos MV. Violência nas relações de intimidade: Estudo sobre a mudança psicoterapêutica na mulher. Braga: Instituto de Educação e Psicologia, Universidade do Minho; 2006.

23. Secretaria de Políticas de Saúde, Ministério da Saúde. Violência intra-familiar: orientações para práticas em serviço. Brasília: Ministério da Saúde; 2003.

24. Kiss LB, Schraiber LB. Temas médico-sociais e a intervenção em saúde: a violência contra mulheres no discurso dos profissionais. Ciênc Saúde Coletiva 2011; 16:1943-52.

25. Zuma CE, Mendes CHF, Cavalcante LF, Gomes R. Violência de gênero na vida adulta. In: Njaine K, Assis SG, Constantino P, organizadores. Impactos da violência na saúde. Rio de Janeiro: Editora Fiocruz; 2009. p. 149-96.

26. Angola. Lei 25/11: contra a violência doméstica. Diário da República, Órgão Oficial da República de Angola 2011; I Série, n. 133, 14 jul.

27. De Ferrante FG, Santos MA, Vieira EM. Violência contra a mulher: percepção dos médicos das unidades básicas de saúde da cidade de Ribeirão Preto, São Paulo. Interface Comun Saúde Educ 2009; 13:287-99.

28. Organización Mundial de Salud. Estudio multipaís de la OMS sobre salud de la mujer y violencia doméstica: primeros resultados sobre prevalencia, eventos relativos a la salud y respuestas de las mujeres a dicha violencia: resumen del informe. Geneva: Organización Mundial de Salud; 2005.

29. Schraiber LB, d'Oliveira AF, Hanada H, Figueiredo W, Couto M, Kiss L, et al. Violência vivida: a dor que não tem nome. Interface Comun Saúde Educ 2003; 7:41-54.

30. Correia MSM, Lopes RLM, Diniz NMF. Reflexões sobre o cuidar de mulheres que sofrem violência conjugal em uma perspectiva heideggeriana do mundo da técnica. Rev Esc Enferm USP 2001; 35:223-9.

31. Gomes NP, Diniz NMF, Silva Filho CC, Santos JNB. Enfrentamento da violência doméstica contra a mulher a partir da interdisciplinaridade e intersetorialidade. Rev Enferm UERJ 2009; 17:14-7. 
32. Oliveira EM, Barbosa RM, Moura AAVMM, Kossel $\mathrm{K}$, Morelli K, Botelho LFF, et al. Atendimento às mulheres vítimas de violência sexual: um estudo qualitativo. Rev Saúde Pública 2005; 39:376-82.

33. Brasil. Lei no 11.340, de 7 de agosto de 2006. Diário Oficial da União 2006; 8 ago.

34. Lettiere A, Nakano MAS, Rodrigues DT. Violência contra a mulher: a visibilidade do problema para um grupo de profissionais de saúde. Rev Esc Enferm USP 2008; 42:467-73.

35. Angola. Decreto Presidencial no 262/10. Política Nacional de Saúde. Diário da República, Órgão Oficial da República de Angola 2010; I Série, n. 222, 24 nov.

36. Schraiber LB, D’Oliveira AFPL, França Junior IF. Violência sexual por parceiro íntimo entre homens e mulheres no Brasil urbano, 2005. Rev Saúde Pública 2008; 42 Suppl 1:127-37.
37. Jong LC, Sadala MLA, Tanaka ACD. Desistindo da denúncia ao agressor: relato de mulheres vítimas de violência doméstica. Rev Esc Enferm USP 2008; 42:744-51.

38. Vieira LB, Pandoin SMM, Landerdahl MC. A percepção de profissionais da saúde de um hospital sobre a violência contra as mulheres. Rev Gaúch Enferm 2009; 30:609-16.

39. Minayo MCS, Deslandes SF. Análise diagnóstica da política nacional de saúde para redução de acidentes e violências. Rio de Janeiro: Editora Fiocruz; 2007.

Submitted on 21/May/2013

Final version resubmitted on $04 /$ Oct/2013

Approved on 14/Nov/2013 